\title{
CLINICAL STUDY OF BREAST ABSCESS IN LACTATING AND NON LACTATING WOMEN
}

\author{
Harindranath H. R', Ravikar Jayraj2, Bharathi $S^{3}$
}

${ }^{1}$ Associate Professor, Department of General Surgery, Bangalore Medical College and Research Institute.

${ }^{2}$ Assistant Professor, Department of General Surgery, Bangalore Medical College and Research Institute. ${ }^{3}$ Post Graduate, Department of General Surgery, Bangalore Medical College and Research Institute.

\section{ABSTRACT}

\section{BACKGROUND}

Aim of the study was to evaluate the clinical presentation, early diagnosis and treatment of breast abscess in lactating and nonlactating women.

\section{METHOD}

This is a prospective study of 30 patients in the hospital. The effectiveness of early diagnosis of mastitis and its treatment, incidence among lactating and non-lactating women, the period of lactation most commonly affected were studied.

\section{RESULTS}

- Incidence among lactating was 73.3\%.

- Incidence among non-lactating was $26.7 \%$.

- $\quad$ Early diagnosis by USG was in $2 \%$.

- Most common pathogen being staphylococcus aureus.

\section{CONCLUSION}

- $\quad$ Early diagnosis is possible with early reporting of symptoms and confirmation with USG.

- Incision and drainage is better modality as compared to percutaneous needle aspiration.

- Incidence more common during weaning period.

- Diabetics common cause in non-lactating women.

\section{KEYWORDS}

Breast Abscess, Early Diagnosis, Incision and Drainage.

HOW TO CITE THIS ARTICLE: Harindranath HR, Jayraj R, Bharathi S. “Clinical study of breast abscess in lactating and non-lactating women.” Journal of Evolution of Medical and Dental Sciences 2015; Vol. 4, Issue 103, December 24; Page: 16844-16845, DOI: $10.14260 /$ jemds/2015/2530

\section{INTRODUCTION}

Breast abscess is localized collection of pus in the breast tissue due to complication of mastitis in lactating mothers. It occurs rarely outside lactation period. ${ }^{1}$

Afflicts $9-33 \%$ of all lactating women and abscess as complication of mastitis in up to $11 \%$ of time.

Staphylococcus aureus being the most common pathogen seen in up to $100 \%$ of culture confirmed cases. ${ }^{2}$

Breast abscess in non-lactating women is rare mean age of 35-39 years, most common risk factor being diabetics mellitus, $90 \%$ are subarealor abscess. ${ }^{3}$

\section{Risk of Mastitis}

- Poor positioning.

- Poor attachment of baby.

- Nipple retraction.

- $\quad$ Cracked nipple.

- Trauma to the breast/nipple.

- Abrupt weaning.

- Long interval between feeds.

Financial or Other, Competing Interest: None.

Submission 04-12-2015, Peer Review 05-12-2015,

Acceptance 18-12-2015, Published 23-12-2015.

Corresponding Author:

Dr. Harindranath $H . R$

No.1852/3, $1^{\text {th }}$ Cross,

Prakash Nagar,

Bangalore-560021.

E-mail: harindranath82@gmail.com

DOI:10.14260/jemds/2015/2530
- No hygiene/proper cleaning of nipple before feeding

- Oral hygiene of the baby.

Risk Factor for Breast Abscess

- Inadequately treated mastitis.

- Weaning during episodes of acute mastitis.

\section{DIAGNOSIS}

Any female patient presenting to the hospital with fever associated with chills and rigor, pain in the breast, skin changes in the breast, i.e. increased redness, tenderness in the breast associated with sore or crack nipple, breast engorgement, unable to feed the child were examined.

Based on clinical finding and examination of breast patients were subjected to USG in case of early presentation, patient with formed abscess underwent incision and drainage or percutaneous aspiration and pus was sent for culture and sensitivity.

Patients were treated on anti-inflammatory and antibiotics and followed up for a duration of 6 months.

\section{MATERIALS AND METHODS STUDY DESIGN}

This was a single center prospective study conducted by Department of Surgery, Bowring and Lady Curzon Hospital, a total of 30 patients were included in the study during June 2014-June 2015. The protocol was approved by ethical committee of the Institution, written informed consent was obtained from all participants. 


\section{PARTICIPANTS}

The patients were selected from those attending the outpatient department, emergency and inpatient Department of Bowring and Lady Curzon Hospital. The age of the patient varied between 18-55 years most patients falling within the range of 20-25 years in lactating women, more than 35 years in non-lactating women.

All patients diagnosed to have pain with mastitis/breast abscess based on clinical and USG findings were included in the study.

\section{Exclusion Criteria:}

- Benign breast disease.

- Inflammatory breast carcinoma.

- Tubercular breast abscess.

- Thirty patients were enrolled, 20 were lactating, 10 nonlactating.

\section{METHODS}

All subjects satisfying the criteria were carefully worked up in terms of detailed history and clinical examination. Lab and imaging investigation included complete heamogram, RBS, urine routine, USG breast and other investigation as per specific indications.

An informed consent was obtained from the patient and was treated as per protocol all patient received Capsule Augmentin/Flucloxacillin BD for 5 days and Tablet Paracetomol BD for 5 days. The empirical treatment was revised based on culture and sensitivity report; however, patient in whom culture was sterile was continued on same treatment.

\section{Non-pharmacological treatment, i.e. in mild and localized symptoms}

- Enhanced breast milk drainage by physiological methods, i.e. expressing, massage and breast feeding to resolve mastitis.

- Ensure correct positioning and attachment.

- Ensure frequent feeding and effective milk removal.

- Apply warmth to assist set down reflexes.

- Apply cold pack after feed to reduce pain and Oedema.

- For patient with breast abscess after obtaining consent, under aspectic precaution, incision and drainage of abscess carried out under local anesthesia.

\section{Evaluation of Response to Treatment/Intervention}

The clinical response, i.e. decrease in temperature, pain were evaluated on daily basis. The patients who underwent I and D, besides monitoring of clinical response daily dressing/drainage of abscess was done. In patient with early diagnosis of mastitis were started on Tablet Flucloxacillin and Paracetomol and further progression noted, no further progression noted.
In patient with small single abscess $<5 \mathrm{~cm}$ size percutaneous aspiration was done and was repeated for 2 setting on alternate day basis.

\section{Followup}

The patients were followed up weekly for a month and on monthly basis for 6 months.

\section{STATISTICAL ANALYSIS}

Incidence of Breast Abscess

\begin{tabular}{|c|c|c|}
\hline & Cases & Percentage \\
\hline Lactating mothers & 22 & $73.3 \%$ \\
\hline Non-lactating mothers & 8 & $26.7 \%$ \\
\hline
\end{tabular}

Incidence of Diabetic in Non-Lactating Mothers

\begin{tabular}{|c|c|c|}
\hline Non-Lactating Mothers & Cases & Percentage \\
\hline Diabetic & 4 & $50 \%$ \\
\hline Non-Diabetic & 4 & $50 \%$ \\
\hline
\end{tabular}

\section{Incidence based on months of Lactation}

\begin{tabular}{|c|c|c|}
\hline Month & Cases & Percentage \\
\hline <1 Month & 4 & $18 \%$ \\
\hline 1-2 Month & 2 & $9 \%$ \\
\hline 3-4 Month & 3 & $13.7 \%$ \\
\hline 5-6 Month & 8 & $36.3 \%$ \\
\hline 7-8 Month & 4 & $18 \%$ \\
\hline 9-10 Month & 0 & 0 \\
\hline 11-12 Month & 1 & $4.5 \%$ \\
\hline
\end{tabular}

- Incidence with cracked nipple - 4 cases $-18 \%$.

- Incidence with top feeds -18 cases $-72.5 \%$.

- Incidence of early diagnosis with USG -2 cases $-6.7 \%$.

\section{DISCUSSION}

Due to the delicate nature of breast tissue early diagnosis and treatment of breast abscess/mastitis is essential. Delay/inadequate management may lead to tissue destruction, chronic infection, periductal fistulas and breast deformities.

\section{REFERENCES}

1. Rizzo M, Gabram S, Staley C, Peng L, Frisch A, Jurado M, et al. Management of breast abscesses in non-lactating women. Am Surg. 2010;Mar;76(3):292-5.

2. Branch-Elliman W, Golen TH, Gold HS, Yassa DS, Baldini LM, Wright SB. Risk factor for staphylococcus aureus postpartum breast abscess. Clinical infectious disease. 2012 Jan 1;54(1):71-7.

3. Eryilmaz R, Sahin M Hakan, Tekelioglu M, et al. Management of lactation breast abscess. Breast. 2005 Oct;14(5):375-9. 